\title{
16. Literary World-Making under Apartheid: Staffrider and the Location of Print Culture
}

Stefan Helgesson

English, Stockholm University

The fields of (literary) postcolonial studies and world literature stand in an uneasy relationship to each other, not least because of their divergent approaches to literary value. ${ }^{\mathrm{I}}$ If postcolonial scholars endeavour to reevaluate the devalued and bring that which has been marginalised, repressed or silenced to public attention, world literature has focused on that which is already valued. By looking at works that have "gained in translation", at processes of international canonisation or at the hierarchy of the "world republic of letters", important contributions to world literary scholarship have had a tautological tendency: they have confirmed what we already know, namely that some centres of publication and reception (Paris, New York, London) are more influential than others

${ }^{1}$ For examples of these debates, see Pascale Casanova, "Literature as a World", New Left Review 3I (2005): 7I-90; Peter Hitchcock, The Long Space: Transnationalism and Postcolonial Form (Stanford: Stanford University Press, 2010); Stefan Helgesson, "Postcolonialism and World Literature: Rethinking the Boundaries", Interventions I6, no. 4 (2014): 483-500; Aamir Mufti, Forget English! Orientalisms and World Literatures (Cambridge: Harvard University Press, 20I6); Mads Rosendahl Thomsen, Mapping World Literature: International Canonization and Translation Literatures (London: Continuum, 2008).

How to cite this book chapter:

Helgesson, Stefan. "Literary World-Making under Apartheid: Staffrider and the Location of Print Culture". In World Literatures: Exploring the Cosmopolitan-Vernacular Exchange, edited by Stefan Helgesson, Annika Mörte Alling, Yvonne Lindqvist, and Helena Wulff, I7I-I 84. Stockholm: Stockholm University Press, 20I8. DOI: https://doi.org/IO.I6993/bat.p. License: CC-BY. 
(Lagos, Warsaw, Jakarta), and that only the work of a select few writers achieves global prominence. ${ }^{2}$

Understanding the complex ways in which literary value accumulates and is consolidated is no trivial matter. On the contrary, criticism of "the canon" has often downplayed two things. The first is that canonicity is not a voluntaristic matter. One does not dismantle a canon simply by presenting a new list of writers and works that ought to be valued. The second is that each critical intervention will in itself count as a bid in the unpredictable, drawn-out construction of canonicity. (And it is, as J. M. Coetzee once observed, not least when under attack that the canonical status of a particular work is confirmed. ${ }^{3}$ ) Indeed, it makes more sense to tie the question of canonicity to how different interpretive communities each will attach value to certain sets of works be they Shakespeare's plays, Kendrick Lamar's hiphop lyrics or Sudanese poetry. Such a perspective will show that the conflict has less to do with canonicity per se than with social inequalities between interpretive communities. ${ }^{4}$

The specific problem broached in this chapter, however, has to do with the relevance of the "world" perspective in relation to literary value. Or more to the point: Can the cosmopolitan paradigm of world literature advance our understanding of local, vernacular constructions of literary value? Are there, in other words, productive points of intersection between the concerns of world literature studies and postcolonialism that can advance our understanding of literary world-making? The short answer is yes, although this brief piece can only begin to explain why. My empirical case is the South African literary journal Staffrider (especially its March I979 issue), and my theoretical point of entry is

${ }^{2}$ See e. g. David Damrosch, What Is World Literature? (Princeton: Princeton University Press, 2003); Pascale Casanova, La république mondiale des lettres (Paris: Seuil, I999).

3 J. M. Coetzee, "What Is a Classic?", Current Writing 5, no. 2 (I993): 20.

${ }_{4}^{4}$ For more on critiques - and defences - of canonicity, see John Guillory, Cultural Capital: The Problem of Literary Canon Formation (Chicago: Chicago University Press, I993); Harold Bloom, The Western Canon: The Books and School of the Ages (New York: Harcourt Brace, I994); Thomsen, Mapping. 
the concept of "world-making". The specific choice of the I979 issue is abitrary, but my focus on the the early period of Staffrider is not, given the journal's experimental editorial practice at the time - as I soon shall explain. The effectiveness of Staffrider as a world-making enterprise, often in direct conflict with state power, can, I claim, be attributed to a cultivation of literary value that harnessed formal, linguistic and canonical resources of a wider literary world for local ends. Hence, properly accounting for its significance in the history of South African literature requires that we move beyond its immediate location and moment, and adopt a broader and deeper analytical framework that recognises the relative autonomony of literature as an aspect of its world-making capacity. In its generality, this may seem like a harmless claim, but its interest lies in how such a harnessing of resources is done - and also how this may adjust or even challenge the received South African understanding of Staffrider's importance.

First a few words on "world" and "world-making". As Eric Hayot usefully points out, there are two different, even opposed, uses of the term "world" in current world literature scholarship. The first is exemplified by the approaches of Pascale Casanova and Franco Moretti. Here, "'world' refers not to the actual world but to the total enworldedness, or world-constituting force, of a system." 5 The second, by contrast, does in fact invoke the actual world by taking upon itself the duty to expand literary study across linguistic and geographical boundaries. This is, essentially, the approach that has been cultivated by David Damrosch, but also by other scholars such as Anders Pettersson, Gunilla Lindberg-Wada and Alexander Beecroft. ${ }^{6}$

The "world", then, can be an enclosed, self-supporting entity. Or it can denote the ungraspable totality of the actual world - by

5 Eric Hayot, On Literary Worlds (Oxford: Oxford University Press, 2OI2), 3 I.

${ }^{6}$ Alexander Beecroft, An Ecology of World Literature (London: Verso, 2015); Damrosch, World Literature; Gunilla Lindberg-Wada, ed., Literary Genres: An Intercultural Approach (Berlin: De Gruyter, 2006); Anders Pettersson, ed., Notions of Literature Across Times and Cultures (Berlin: De Gruyter, 2006). 
which is normally meant the planet Earth and everything that it contains. This conceptual tension between "world" as a part within a bigger whole and "world" as that bigger whole itself must however be understood precisely as a tension between positions on a sliding semantic scale, and not as an absolute difference. This is because the actual world exceeds our conceptual, perceptual and cognitive grasp. The actual world - even if we restrict ourselves to a specific realm such as literature - will always be more than an individual consciousness can fathom. It is for that reason that Moretti famously stated that "[r]eading 'more' is always a good thing, but not the solution", and that therefore "world literature is not an object, it's a problem". 7 But that is also why the problem needs to be reformulated again and again, lest we otherwise fall back on habit and risk mistaking our partial conception of the world with the actual world. ${ }^{8}$

What happens, then, if we think of "world" and "literature" in terms of world-making? The term has previously been elaborated by, among others, Nelson Goodman, Mario Valdés and Pheng Cheah, and it directs our attention to an activity rather than something given. ${ }^{9}$ The world of world-making is not simply "there", it is in process. It is obviously not the same as the actual world in its entirety, but nor is it exclusively a self-enclosed system. Rather, the world of world-making refers more openly to

7 Franco Moretti, "Conjectures on World Literature", New Left Review I (2000): 55 .

${ }^{8}$ A striking historical instance of a deliberately partial yet planet-wide world-conception would be "the Third World", coined first in French as le tiers monde in the I950s, and then gaining currency in the I960s phase of decolonisation - specifically as a contrast to the binary world-conception of the Cold War.

9 Nelson Goodman, Ways of Worldmaking (Indianapolis: Hackett, I978); Mario J. Valdés, World-Making: The Literary Truth-Claim and the Interpretation of Texts (Toronto: Toronto University Press, I992); Pheng Cheah, What Is a World? Postcolonial Literature and World Literature (Durham: Duke University Press, 2016). See also Nathalie Karagiannis and Peter Wagner, eds., Varieties of World-Making (Cambridge: Cambridge University Press, 2007) and Vera Nünning, Ansgar Nünning and Birgit Neumann, eds., Cultural Ways of Worldmaking: Media and Narrative (Berlin: De Gruyter, 2010). 
the domain of human activity and to the world as a relational modality.

One way to make sense of this is to introduce a threefold distinction between planet, globe and world. The planet, as Gayatri Spivak once wrote, is "in the species of alterity, belonging to another

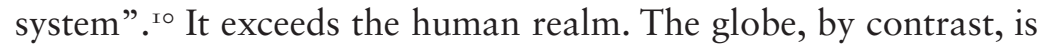
an abstraction that conceives of the planet Earth according to the needs and protocols of - in particular - finance capital, thereby imposing the same system of exchange everywhere. As Spivak puts it, "[n]o one lives there". ${ }^{\text {II }}$ The world, finally, is a term that could be reserved precisely for the human domain. Here we may draw on Hannah Arendt, who used the world-concept to denote that which humans construct as a common, public world:

the term "public" signifies the world itself, in so far as it is common to all of us and distinguished from our privately owned place in it. This world, however, is not identical with the earth or with nature, as the limited space for the movement of men and the general condition of organic life. It is related, rather, to the human artifact, the fabrication of human hands, as well as to affairs which go on among those who inhabit the man-made world together. To live together in the world means essentially that a world of things is between those who have it in common, as a table is located between those who sit around it; the world, like every in-between, relates and separates men at the same time. ${ }^{\mathrm{I2}}$

But besides its public, in-between nature, the world in this sense also has a privileged relationship with time. In Arendt's understanding, it bestows "a measure of permanence and durability upon the futility of mortal life and the fleeting character of human time". ${ }^{\mathrm{I}}$ This is the understanding that has been developed in particular by Pheng Cheah, for whom "world" is a temporal rather than spatial category: "[a] world only is and we are only worldly

ı Gayatri Spivak, Death of a Discipline (New York: Columbia University Press, 2003), 72.

ir Spivak, Discipline, 72.

${ }^{12}$ Hannah Arendt, The Human Condition (Chicago: University of Chicago Press, I958 [I998]), 52.

${ }^{13}$ Arendt, Human Condition, 8. 
beings if there is already time. The unity and permanence of a world are thus premised on the persistence of time." ${ }^{\mathrm{I}}$ If we read Cheah and Arendt together, it becomes evident that "world" - in this sense - is completely dependent on the collective, diachronic activity of humans. No individual can make a world alone, but no world will exist and persist without a succession of individual makers and collaboration between them.

Literature is from that point of view a particular and peculiar instance of world-making. Thanks to their durability and withdrawal from sheer utility, Arendt sees works of art as being "the most intensely worldly of all tangible things". ${ }^{15}$ Yet literature, understood as verbal art, is a strangely intangible art form. Or rather, its tangibility - as print, script or as soundwaves - could be seen merely as the enabler of intangible semantic and affective qualities of language. Language is nonetheless one of the strongest and most pervasive instruments of human world-making. Language is always "in-between". It is never private or individual, but exists only through a community of speakers. Language (understood as a set of specific semiotic practices) is also much more durable than the individual: it is there before the individual is born and will - normally persist long after the death of the individual speaker. Literature can thereby be seen as harnessing the world-making force of language by creating - to use Hayot's term - an "aesthetic world". ${ }^{16}$

Such an aesthetic world is, self-evidently, not the same as the world in the sense of the unfathomable totality of everything. An aesthetic world forms part of the human world in Arendt's sense, and is - in so far as we are speaking of literature - bound to the particular language or combination of languages in which it is composed and, more pointedly, to the medium through which it is presented. This importance of language and medium is in fact ignored by Cheah and Hayot alike, and yet it is central to understanding the world-making capacity (and limitations) of literature. When Hayot observes that worldedness "emerges as the unconscious of the work, as the establishing rules that constitute

\footnotetext{
${ }^{14}$ Cheah, What Is a World?, 2.

I5 Arendt, Human Condition, I67.

I6 Hayot, Literary Worlds, 54.
} 
the work as a whole", I would therefore add that language and medium are among the most fundamental aspects of that unconscious. ${ }^{17}$ As such, they have a formative impact on literature's worldledness that far exceeds momentary political exigencies.

To test this claim, let us look a bit closer at our case in point, Staffrider. Launched in I978, Staffrider represented a new departure for South African literary culture. It is most famous for its "populist" ethos, eschewing not only "elite" standards of literary taste but also true and tried editorial practices - in its early years, the magazine devolved editorial responsibility for selection on community-based writers' groups. It would keep appearing until I996, but it was most innovative in its first ten years, making a mark on South African literature that few, if any, other journals have made. It "both challenged and transformed the social image and meaning of literature in South Africa", in the wording of an early assessment by Michael Vaughan. ${ }^{18}$ David Maughan-Brown would later add that it had been particularly successful "in shaking up literary critical assumptions and expectations and putting important theoretical issues, such as the relationship between individual authorship and community cultural production, firmly on the South African cultural agenda". ${ }^{19}$

If this interventionist populism - which was also roundly criticised from both liberal and Marxist vantage points - hints at Staffrider's importance, it is just as crucial to recognise that it did not just spring up organically like a tree from the ground. The world-making force of Staffrider had structural, cultural and political preconditions. It was published by Ravan Press, the flagship radical publisher in South Africa in the I970s, supported in part by external donors. ${ }^{20}$ The magazine emerged on the back of intensified political mobilisation against the apartheid state, especially following the Soweto uprising in I976. Above all, it

${ }^{17}$ Hayot, Literary Worlds, 54.

${ }^{\text {s }}$ Michael Vaughan, "Literature and Populism in South Africa: Reflections on the Ideology of Staffrider", in Georg M. Gugelberger, ed., Marxism and African Literature (London: James Currey, I985), I95.

19 David Maughan-Brown, "The Anthology as Reliquary?", Current Writing I, no.I (I989): 3 .

${ }^{20}$ Peter D. McDonald, The Literature Police: Apartheid Censorship and Its Cultural Consequences (Oxford: Oxford University Press, 2009), I35. 
published work by "community" writers side by side with a vast array of already established writers and critics such as Miriam Tlali, Es'kia Mphahlele, Nadine Gordimer, J. M. Coetzee, Njabulo Ndebele, Mtutuzeli Matshoba, Peter Wilhelm and Richard Rive. In so far as "politics" and "literature" can be regarded as distinct from each other, Staffrider's effectiveness derived in no small degree from viewing literature and the aesthetic not in isolation from, but as situated within a heavily politicised and repressive context. As its founding editor Mike Kirkwood would write retrospectively about the early years:

The oddest thing about Staffrider was always this: that it was a literary magazine. Yet it was. Of course, one could turn this statement around and say that the odd thing about most of its contributors was that they were writers. Yet they were. It happened, at that time in South Africa, that literature became overburdened with a number of other social and political functions. While only a narrow view of literature would exclude these functions from among those literature can perform, it is true that existing literary forms must undergo a considerable development before they begin to be adequate to these "new" functions [...]. By the same token, it happened that an unusual number of people found they could best participate in the making of new society, or best pursue their more personal aspirations, by writing. ${ }^{2 \mathrm{I}}$

Kirkwood's point is borne out if we look closer at our chosen example, the March 1979 issue (which also happened to be one of the issues that were banned by the authorities). What we find here, organised in characteristically unhierarchical fashion, is a substantial collection of poems, short stories, reviews and drawings, plus a hands-on “workshop” piece by Es'kia Mphahlele on the craft of writing short stories. The cover image sports a fantasy creature, half-bird, half-human, ready to take flight, whereas the drawings inside the magazine almost all depict individuals mostly faces - in bare or unspecified environments.

${ }^{21}$ Mike Kirkwood, "Remembering Staffrider", in Ten Years of Staffrider, ed. Andries Oliphant and Ivan Vladislavić, Staffrider 7, no. 3-4 (I988): 3 . 


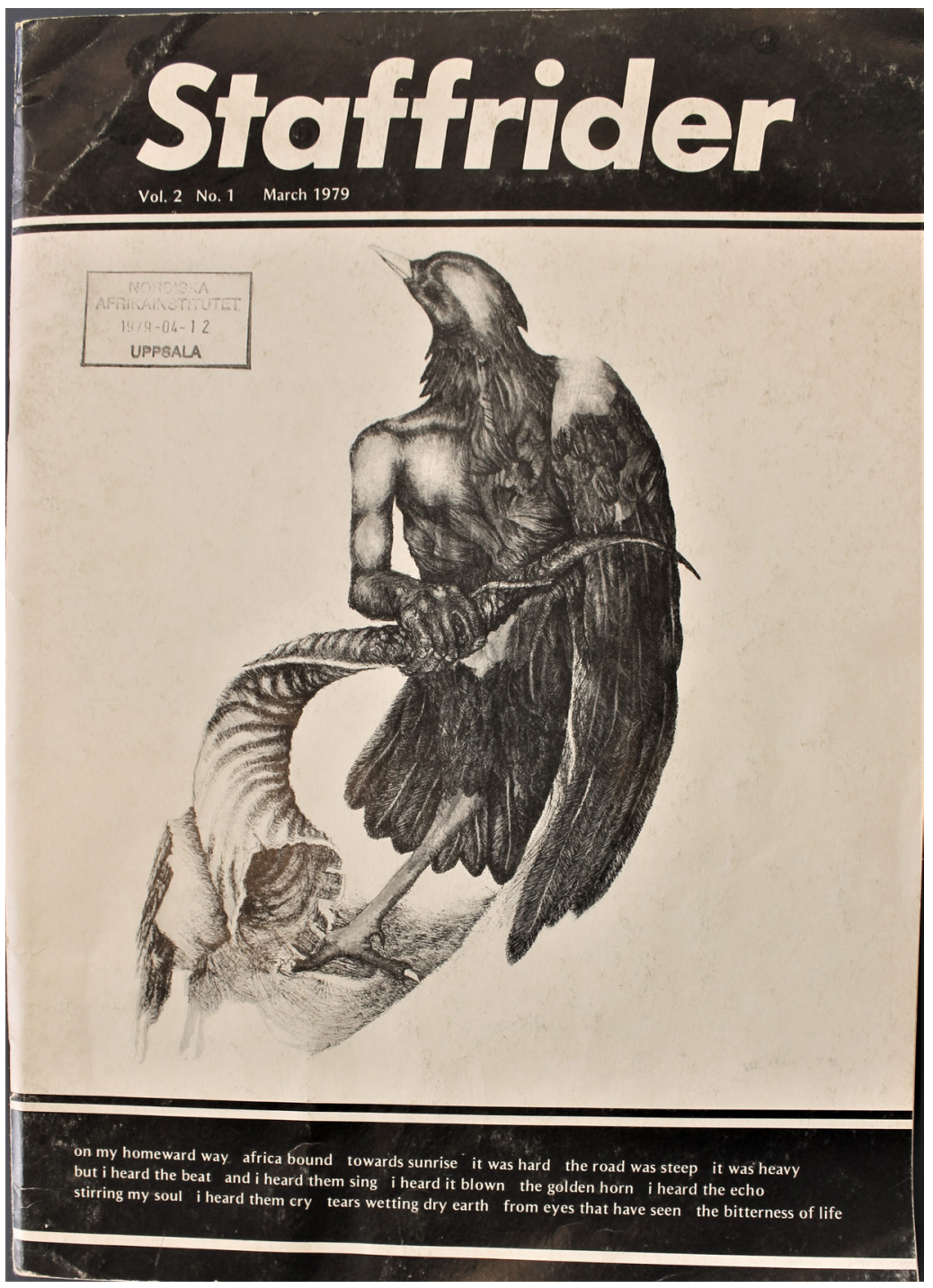

Figure 2. Cover from Staffrider I, I979. Artist: Harry Moyaga. Copyright: Unknown. License: CC BY. Repeated but unsuccessful attempts have been made to identify and contact the copyright holder. If the rights holder contacts the author, this situation will be rectified. Image taken by Stefan Helgesson. 
The content of this Staffrider issue is in other words almost exclusively literary and aesthetic. Its 60 pages contain no commercial advertising (a striking contrast to the South African I950s journal Drum, for instance) but is instead filled with the work of both established and emergent writers. Most sections are organised according to the provenance of the published material. Indeed, an entire map of South Africa is sketched out as work by writers from Rustenburg, Kimberley, Katlehong, Soweto, Sharpeville, Sebokeng, Cape Town, and so on, is presented on the pages. This is, notably, an alternative map of the country which highlights not least the townships created by apartheid policies, rather than the official "white" geography of the country (to which Cape Town and Kimberley belonged).

A similarly discrepant sense of locality is produced not only by the frequent inclusion of words marked as vernacular in the English-language texts, but also by a number of poems in languages such as Sotho, Xhosa and Zulu. With English being by far the dominant language in the journal, it is notable how often writers incorporate especially Afrikaans terms ("nie-blankes", "baas", "skollies", "knobkieries") - often precisely to confirm the negative association of Afrikaans with state power at this time. Phrases in African languages occur more commonly in the poetry, as in Magoleng wa Selepe's well known "My Name". Here, the meaning of the name Nomgqibelo Ncamisile Mnqhibisa is both the point of the entire poem - "Look what they have done to my name [...] to this man it is trash [...] I end up being / Maria ..." and at the same time withheld from readers who don't know an Nguni language (Xhosa or Zulu).22

This is arguably the point at which something we might call "strategic vernacularism" is most effectively deployed in this issue of Staffrider. If the frequent invocation of place names, township settings and demotic registers of language all contribute to creating irreducibly local bonds between the magazine and its South

${ }_{22}$ Staffrider I (I979), 7. The name is in Xhosa. "Nomgqibelo" bears reference to "Saturday", and "Ncamisile" means "kissed". "Mnqhibisa" is apparently just a surname with no particular meaning. Heartfelt thanks for Uhuru Phalafala for her help in deciphering the words. 
African readers, Selepe's poem exploits this multilingual ethos in such a way as to highlight a rift between worlds. It rejects, effectively, the world-making force of the English language - at least on the terms of "white" power - and endorses instead the resonance and temporal depth of not just the Xhosa name but of the entire Xhosa world that it metonymically invokes.

But rather than simply reaffirming the vernacular tendency in Staffrider, what needs to be foregrounded here is how this vernacularism derives much of its force from the journal's cultivation of a literary ethos that is not reducible to locality or to a supposedly national culture, but is a mode of cosmopolitanism in its own right. In Mphahlele's guide to writing short stories, he presents a long list of writers whom he regards as indispensable models for the budding writer. Among these can be noted Ernest Hemingway, Richard Wright, Anton Chekhov, Nikolai Gogol, James Joyce, Ama Ata Aidoo, Chinua Achebe, Luís Bernardo Honwana, Nadine Gordimer and Can Themba. ${ }^{23}$ Similarly, in a review of a new edition of Sol Plaatje's classic novel Mbudi, the critic Mshengu reads it in relation to, among other things, Chinua Achebe's novel Things Fall Apart and Modikwe Dikobe's The Marabi Dance. ${ }^{24}$ In the poetry, imaginary geographies consisting particularly of Africa/Afrika, but also of Mecca, India, Holland, Vietnam, Cuba and Australia - the latter in an allusion to the Nobel Prize-winning author Patrick White - are established. ${ }^{25}$

These examples alone indicate that the local literary value of Staffrider is in no way isolated from a wider world, either in a literary or a geographical sense. Its mode of address and means of production and distribution are pressured by the exigencies of its time and place; its economic base is partly derived from international support; its symbolic, intellectual and formal resources are drawn from a historical and cosmopolitan repository of genres, names, styles and narrative techniques that could be defined as a "world" of literature with its own, inconsistently distributed affordances. If we look at what enables Staffrider's existence on

23 Staffrider I (I979), 50.

${ }_{24}$ Staffrider I (1979), 55.

25 Staffrider I (I979), 48, 49. 
even more fundamental levels - such as the reliance on English as a vehicular language, the print medium, the use of the Latin alphabet, the generic conventions of lyric poetry and the short story - it becomes evident how it is entangled in a longue durée of literary and literate culture that derives from no single place, but has been formed historically across centuries and is implicated transnationally in the politics of its Cold War moment. In this way, Staffrider's contribution to making the world differently in the late-apartheid temporality of crisis is itself made possible by longer, and deeply ambiguous, histories of world-making.

To conclude, Staffrider presents us with a strong instance of the construction of local literary value under adverse circumstances. With respect to an Arendtian understanding of "world" as that which is constructed collectively by humans, it contributed to alternative forms of world-making that interlocked with the world-destroying forces of racialised state power at the time. This was done, however, by cultivating a dialectic between the intensely local and expansively cosmopolitan dimensions of literature, the impact of which was attributable to the convergence of national anti-apartheid activism, alternative publishing structures and a coalition of widely but differentially networked writers and editors. This allowed the magazine to work in canonical and noncanonical registers at one and the same time - or rather, it causes us to question the explanatory value of opposing the canonical and non-canonical, as has been common in critical commentary on Staffrider. It is in this respect that the concept of "worldmaking" provides another way of accounting for its location in the cosmopolitan-vernacular nexus. The vernacular figure of the "staffrider" clinging illegally on trains, a "skelm of sorts" moving between worlds, therfore turns out to be an apt metaphor for its world-literary positioning as well. ${ }^{26}$

${ }_{26}$ Staffrider I (I978), 2. 


\section{Bibliography}

Arendt, Hannah. The Human Condition. I95 8. Chicago: University of Chicago Press, I998.

Beecroft, Alexander. An Ecology of World Literature. London: Verso, 2015 .

Bloom, Harold. The Western Canon: The Books and School of the Ages. New York: Harcourt Brace, I994.

Casanova, Pascale. La république mondiale des lettres. Paris: Seuil, I999.

—. "Literature as a World". New Left Review 3I (2005): 7 I-90.

Cheah, Pheng. What Is a World? Postcolonial Literature and World Literature. Durham: Duke University Press, 2016.

Coetzee, J. M. "What Is a Classic?”. Current Writing 5, no. 2 (I993): 7-24.

Damrosch, David. What Is World Literature? Princeton: Princeton University Press, 2003.

Goodman, Nelson. Ways of Worldmaking. Indianapolis: Hackett, I978.

Guillory, John. Cultural Capital: The Problem of Literary Canon Formation. Chicago: Chicago University Press, I993.

Hayot, Eric. On Literary Worlds. Oxford: Oxford University Press, $20 \mathrm{I} 2$.

Helgesson, Stefan. "Postcolonialism and World Literature: Rethinking the Boundaries". Interventions I6, no. 4 (20I4): 483-500.

Hitchcock, Peter. The Long Space: Transnationalism and Postcolonial Form. Stanford: Stanford University Press, 2010.

Karagiannis, Nathalie and Peter Wagner, eds. Varieties of WorldMaking. Cambridge: Cambridge University Press, 2007.

Kirkwood, Mike. "Remembering Staffrider". In Ten Years of Staffrider, edited by Andries Oliphant and Ivan Vladislavić, Staffrider 7, no. 3-4 (I988): I-9. 
Lindberg-Wada, Gunilla, ed. Literary Genres: An Intercultural Approach. Berlin: De Gruyter, 2006.

Maughan-Brown, David. “The Anthology as Reliquary?”. Current Writing I, no.I (I989): 3-2I.

McDonald, Peter D. The Literature Police: Apartheid Censorship and Its Cultural Consequences. Oxford: Oxford University Press, 2009.

Moretti, Franco. "Conjectures on World Literature". New Left Review I (2000): 54-68.

Mufti, Aamir R. Forget English! Orientalisms and World Literatures. Cambridge: Harvard University Press, 2016.

Nünning, Vera, Ansgar Nünning and Birgit Neumann, eds. Cultural Ways of Worldmaking: Media and Narrative. Berlin: De Gruyter, 2010.

Pettersson, Anders, ed. Notions of Literature Across Times and Cultures. Berlin: De Gruyter, 2006.

Spivak, Gayatri Chakravorty. Death of a Discipline. New York: Columbia University Press, 2003.

Staffrider I (1978).

Staffrider I (I979).

Thomsen, Mads Rosendahl. Mapping World Literature: International Canonization and Transnational Literatures. London: Continuum, 2008.

Valdés, Mario J. World-Making: The Literary Truth-Claim and the Interpretation of Texts. Toronto: Toronto University Press, I992.

Vaughan, Michael. "Literature and Populism in South Africa: Reflections on the Ideology of Staffrider". In Marxism and African Literature, edited by Georg M. Gugelberger, I95-220. London: James Currey, I985. 